\title{
APPLICATION OF LAPLACE TRANSFORM TO THE FREE VIBRATION OF CONTINUOUS BEAMS
}

\author{
WEN H.B. ${ }^{1}$, ZENG T. ${ }^{2}$, HU G.Z. ${ }^{3}$
}

\begin{abstract}
Laplace Transform is often used in solving the free vibration problems of structural beams. In existing research, there are two types of simplified models of continuous beam placement. The first is to regard the continuous beam as a single-span beam, the middle bearing of which is replaced by the bearing reaction force; the second is to divide the continuous beam into several simply supported beams, with the bending moment of the continuous beam at the middle bearing considered as the external force. Research shows that the second simplified model is incorrect, and the frequency equation derived from the first simplified model contains multiple expressions which might not be equivalent to each other. This paper specifies the application method of Laplace Transform in solving the free vibration problems of continuous beams, having great significance in the proper use of the transform method.
\end{abstract}

Keywords: Laplace transform, Continuous beam, Vibration, Segmented combination method, Frequency

\section{INTRODUCTION}

Continuous beam structure is very common in construction work, often as continuous beam bridges, beams of buildings, heat exchange tubes in heat exchangers, principal axis in machine tools, and others. As the basis of anti-vibration design, the dynamic characteristic analysis of the structure is indispensable in the design of continuous beam structures.

In order to obtain the dynamic characteristic parameters of continuous beam structures, scholars

\footnotetext{
${ }^{1}$ Associate Professor, PhD. student, College Mechanical Engineering, Sichuan University of Science \& Engineering, Zigong, 643000, China, e-mail: sichuanwhb@suse.edu.cn

${ }^{2}$ Professor, PhD., College Mechanical Engineering, Sichuan University of Science \& Engineering, Zigong, 643000, China, e-mail: 396109721@qq.com

${ }^{3}$ Professor, PhD., College Mechanical Engineering, Sichuan University of Science \& Engineering, Zigong, 643000, China, e-mail: hgzdhx@163.com.
} 
both at home and abroad have conducted a great deal of research on the topic. Based on the mode superposition method and the direct integration method, Dugush [1] used the exact element method to deduce the frequency and vibration mode equation of any and all cross sections of multi-span beams. Li [2] adopted Laplace Transform to deduce the frequency equation of continuous beams, and obtained the frequency equation and vibration mode equation of a two-span simple bearing beam with the same span length. Based on the Bernoulli-Euler beam and Timoshenko beam theories, He [3] took advantage of the dynamic stiffness method to systematically study the vibration of various continuous beams. Yang [4] applied the transfer matrix method to deduce the free vibration modal of continuous beams, then provided a method of acquiring its eigenvalue, and stated the relationship between the bearing number and stiffness and their influences on the inherent frequency of the continuous beams. After the deduction of the vibration equation of double-fold line external prestressed continuous composite beams, Jiao[5] also adopted Laplace Transform to deduce the frequency equation. Different from Reference [2], he divided continuous beams into a symmetric vibration mode and an antisymmetric vibration mode. Cai [6] conducted a field vibration test on a two-span prestressed concrete continuous box girder bridge, and obtained the frequency, damping ratio, and vibration mode of the bridge. Zheng [7] carried out a parameterized experiment with the offset distance of the middle bearing as the variable, and then analyzed the first 3-order frequency and vibration mode changes of two-span continuous beams with different span ratios. Wang [8] also used Laplace Transform to deduce both the frequency equation and the vibration equation of continuous beams. However, Wang's method is different from References [2, 5]. References [2, 5] transformed the statically indeterminate system of a continuous beam into an equivalent static system, meaning a single-span beam with bearing reaction force; while Wang conducted segment treatment on the continuous beams, deducted the vibration equation of each segmental beam, and then established an equation set based on the continuous conditions between each segment and deducted the frequency equation. Shi [9] employed the segmented combination method to establish the vibration equation set of three-span prestressed continuous beams, then gained the analytical solution of the frequency equation and verified the results through the finite element method and real bridge test. Jia [10] studied the influence of a damping oblique angle and span length on the frequencies of anomalous continuous beam bridges through Midas Civil software, and revised the vibration frequency equation in the bridge standards according to the calculated results.

These research achievements improved the theoretical level regarding continuous beam vibration and enhanced the application of continuous beam structures in construction projects. To effectively direct 
practical construction work, the theoretical method should possess the features of simplicity and accuracy.

In the above methods, Laplace Transform is worthy to be noted for its high efficiency and practicability regarding the vibration of beams. The application of Laplace Transform is simple and unique for cases of single-span beam vibration. However, as stated by References $[2,5,8]$, the application method has some differences regarding continuous vibration. In order to specify the application of Laplace Transform to case of continuous beam vibration, it is quite necessary and encouraged to carry out related studies on the application method.

\section{APPLICATION METHOD OF LAPLACE TRANSFORM IN SOLVING CONTINUOUS VIBRATION}

According to References $[2,5,8]$, there are two types of application methods of Laplace Transform in solving continuous beam vibration. The first type is based on single-span beam model. The exact method involves treating the continuous beam as a single-span beam and regarding the reaction force on the middle bearing as an unknown external force on the beam (which has the same frequency as the natural vibration of the beam), and then use Laplace Transform to deduce the frequency equation and vibration function of the continuous beam. The second application method is based on the segmented beam model. Specifically, the method treats the continuous beam in segments and employs the Laplace Transform to deduce the frequency equation and vibration function based on the presence of equivalent corners at the adjacent joints of the two spans.

\section{ANALYSIS OF THE APPLICATION METHOD BASED ON A SINGLE-SPAN BEAM MODEL}

\subsection{VIBRATION EQUATION OF CONTINUOUS BEAMS}

According to References $[2,5]$, the statically indeterminate system of the continuous beam with $n$ bearings in the middle can be transformed into a single-span with $n$ bearing reaction force (As shown in Figure 2). Thereby, the dimensionless vibration equations of single-span and multi-span continuous beams can be uniformly expressed as 


$$
\frac{\partial^{4} \eta}{\partial \xi^{4}}+\frac{\partial^{2} \eta}{\partial \tau^{2}}=\sum_{i=1}^{n} \bar{p}_{i} \delta\left(\xi-\xi_{i}\right)
$$

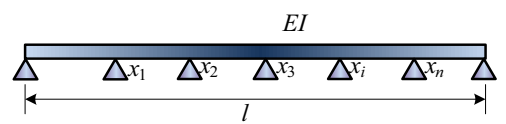

Fig. 1. Multi-span continuous beam system.



Fig. 2. Equivalent system of multi-span continuous beam.

The corresponding constraints are:

$$
\begin{aligned}
& \eta(0, \tau)=0, \eta\left(\xi_{i}, \tau\right)=0(i=1,2,3, \ldots, n), \\
& \eta(1, \tau)=0, \eta^{\prime \prime}(0)=0, \eta^{\prime \prime}(1)=0,
\end{aligned}
$$

where, the following dimensionless variables are same as Reference [11].

\subsection{DEDUCTION OF CONTINUOUS FREQUENCY EQUATION}

During the free vibration of the beam, the frequencies of the middle bearing reaction force and the lateral displacement are the same. In the following equation

$$
\eta(\xi, \tau)=\operatorname{Re}\left[W(\xi) e^{\mathrm{i} \omega \tau}\right], \bar{p}_{i}(\tau)=\operatorname{Re}\left[P_{i} e^{\mathrm{i} \omega \tau}\right] .
$$

Assume $\omega$ is the dimensionless frequency and $\Omega$ is the continuous beam frequency, the relationship between $\omega$ and $\Omega$ will be:

$$
\omega=\left(\frac{M}{E I}\right)^{1 / 2} \Omega l^{2} .
$$

Substitute (3) into (1), we gain:

$$
W^{\prime \prime \prime \prime}-k^{4} W=\sum_{i=1}^{n} P_{i} \delta\left(\xi-\xi_{i}\right)
$$

where, $k^{4}=\omega^{2}$.

Conduct Laplace Transform on (5), we gain:

$$
\hat{W}(s)=\frac{1}{s^{4}-k^{4}}\left[\sum_{i=1}^{n} P_{i} e^{-s \xi_{i}}+s^{3} W(0)+s^{2} W^{\prime}(0)+s W^{\prime \prime}(0)+W^{\prime \prime \prime}(0)\right] .
$$

Conduct Laplace inversion on (6), we obtain the algebraic equation form of a differential equation (5): 


$$
\begin{aligned}
W(\xi)= & \sum_{i=1}^{n} \frac{P_{i}}{2 k^{3}}\left[\sinh k\left(\xi-\xi_{i}\right)-\sin k\left(\xi-\xi_{i}\right)\right] H\left(\xi-\xi_{i}\right)+\frac{\cosh k \xi+\cos k \xi}{2} W(0) \\
& +\frac{\sinh k \xi+\sin k \xi}{2 k} W^{\prime}(0)+\frac{\cosh k \xi-\cos k \xi}{2 k^{2}} W^{\prime \prime}(0)+\frac{\sinh k \xi-\sin k \xi}{2 k^{3}} W^{\prime \prime \prime}(0) .
\end{aligned}
$$

For single-span beams, the first item on the right of (7) is 0 . According to the constraints at the two ends of the beam, we can get:

$$
\left[\begin{array}{cc}
\frac{\sinh k+\sin k}{2 k} & \frac{\sinh k-\sin k}{2 k^{3}} \\
\frac{k(\sinh k-\sin k)}{2} & \frac{\sinh k+\sin k}{2 k}
\end{array}\right]\left[\begin{array}{l}
W^{\prime}(0) \\
W^{\prime \prime \prime}(0)
\end{array}\right]=\left[\begin{array}{l}
0 \\
0
\end{array}\right] .
$$

Assuming the coefficient determinant of (8) is 0 , the frequency equation of the single-span beam will be:

$$
\sin k=0 .
$$

All the frequencies of the single-span beam can be acquired through frequency equation (9). Substitute each frequency into (8), the ratio of related $W^{\prime}(0)$ and $W^{\prime \prime \prime}(0)$ can be obtained. When substituting the ratio into (7), each vibration function of the single-span beam will then be:

$$
W(\xi)=\frac{\sin k \xi}{k}
$$

Regarding continuous beams, $n$ equations can be established according to the constrains provided in (2). The matrix form is:

$$
\left[\begin{array}{cccc}
A_{11} & A_{12} & \cdots & A_{1 n} \\
A_{21} & A_{22} & \cdots & A_{2 n} \\
\vdots & \vdots & & \vdots \\
A_{n 1} & A_{n 2} & \cdots & A_{n n}
\end{array}\right]\left[\begin{array}{c}
P_{1} \\
P_{2} \\
\vdots \\
P_{n}
\end{array}\right]=0
$$

where,

$$
\begin{aligned}
A_{i j}= & H\left(\xi_{i}-\xi_{j}\right)\left[\sinh k\left(\xi_{i}-\xi_{j}\right)-\sin k\left(\xi_{i}-\xi_{j}\right)\right]+\frac{\sin k\left(1-\xi_{j}\right)}{\sin k} \sin k \xi_{i} \\
& -\frac{\sinh k\left(1-\xi_{j}\right)}{\sinh k} \sinh k \xi_{i} . \quad(i, j=1,2,3, \ldots, n)
\end{aligned}
$$


Li [2] took the two-span continuous beams with equivalent lengths as an example, and assuming the coefficient determinant in equation (11) is 0 , the frequency equation of the two-span continuous spam will be:

$$
F_{1}(k)=\frac{\sin ^{2} \frac{k}{2}}{\sin k}-\frac{\sinh ^{2} \frac{k}{2}}{\sinh k}=0
$$

or

$$
F_{2}(k)=\sinh k \cdot \sin ^{2} \frac{k}{2}-\sin k \cdot \sinh ^{2} \frac{k}{2}=0 .
$$

Jiao [5] studied the frequency of two-span external prestressed continuous beams with equivalent lengths, and considered the left part of (11) as the product of two items, where any of them can be 0 . When the vibration of the continuous beam is asymmetric, the reaction force of the middle bearing is 0 , and the frequency equation of the continuous beam is (9); when the vibration of the continuous beam is symmetric, the reaction force of the middle bearing is not 0 , and the frequency equation of the continuous beam is (13), and $\sin k \neq 0$ and $\sinh k \neq 0$.

\subsection{FREQUENCY EQUATION AND FREQUENCY ANALYSIS OF CONTINUOUS BEAMS}

To investigate the differences between Reference [2] and Reference [5], and to understand the characteristics of the frequency equation deducted by Laplace Transform, analysis was conducted in the aspects of equivalent and inequivalent span lengths of continuous beams. The theoretical calculated results are tested by ANSYS software. The main parameters of the continuous beam are shown in Table 1. In the ANSYS simulation, the subspace iteration method is selected to calculate the first six-order frequency of the continuous beam, Unit beam 3 to simulate the continuous beam.

Table 1. Main parameters of the continuous beam.

\begin{tabular}{|c|c|c|c|c|}
\hline Structure parameter & $E(\mathrm{~Pa})$ & $I\left(\mathrm{~m}^{4}\right)$ & $A\left(\mathrm{~m}^{2}\right)$ & $\rho\left(\mathrm{kg} / \mathrm{m}^{3}\right)$ \\
\hline Parameter value & $2 \times 10^{11}$ & $4.5 \times 10^{-8}$ & $6 \times 10^{-4}$ & 7800 \\
\hline
\end{tabular}

\subsubsection{CONTINUOUS BEAMS WITH EQUIVALENT SPAN LENGTH}

According to Reference [5], when the vibrations of two-span continuous beams with equivalent span lengths are asymmetric, their frequency equations are the same as those of single-span beams. As shown in Figure 3, the frequency and vibration mode can be obtained from (9) and (10). Based on the 
vibration mode of the single-span beam, the second-order and fourth-order vibration modes are also two-span continuous beam modes with equivalent span lengths; the third-order vibration mode is a three-span continuous beam mode with equivalent span length; the fifth-order vibration mode is a five-span continuous beam mode with equivalent span length.

With the vibration mode of the single-span beam, only an asymmetric vibration mode and related frequencies can be obtained. Other frequencies have to be rooted from equation (13). As conditions of $\sin k \neq 0$ and $\sinh k \neq 0$ are present, the rooting scope should be $(n \pi, n \pi+\pi),(n=0,1,2, \ldots)$. As shown in Table 2, the first four-order dimensionless frequency of the continuous beam with equivalent span lengths can be obtained.

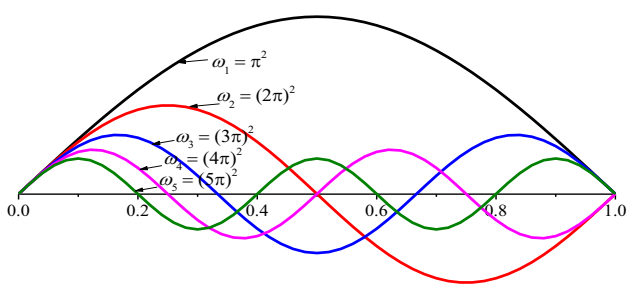

Fig. 3. The first fifth-order vibration mode of single-span beam.

Based on Reference [2], the frequencies of two-span continuous beams with equivalent span lengths can be solved according to equation (13) and equation (14). Both the numerator and denominator of the first item $\sin ^{2}(k / 2) / \sin k$ of $F_{1}(k)$ are sine functions. When $k$ approaches $n \pi$ ( $n$ is even), $\sin ^{2}(k / 2) / \sin k$ approaches 0 as $\sin ^{2}(k / 2)<<\sin k$; when $k$ approaches $n \pi\left(n\right.$ is odd), $\sin ^{2}(k / 2) / \sin k$ approaches infinite. So the rooting scope of equation (13) is $(0, \pi) \cup(n \pi, n \pi+2 \pi),(n=1,3,5, \ldots)$. As shown in Table 2, the first four-order frequency of the continuous beam can be obtained according to equation (13). The change law of $F_{1}(k)$ with $k$ is seen in Figure 4. The change law varies periodically, and $n \pi$ ( $n$ is odd) is the infinite discontinuity point.

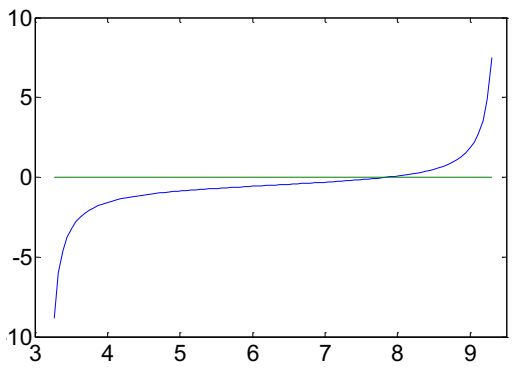

(a) Change law of $F_{1}(k)$ around $\omega_{1}$ point.

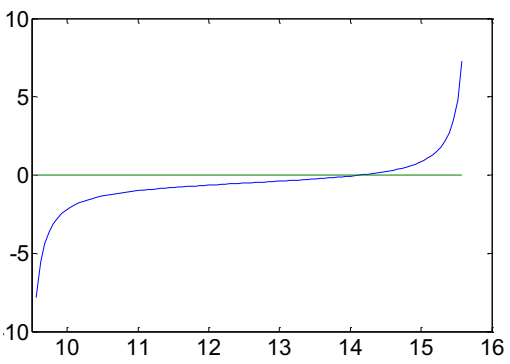

(b) Change law of $F_{1}(k)$ around $\omega_{2}$ point. 


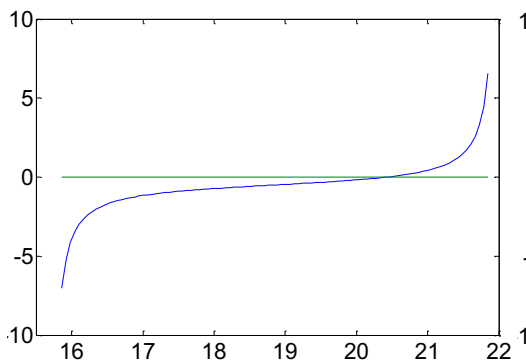

(c) Change law of $F_{1}(k)$ around $\omega_{3}$ point.

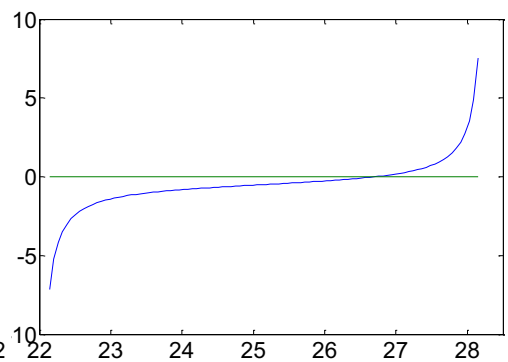

(d) Change law of $F_{1}(k)$ around $\omega_{4}$ point.

Fig. 4. Change law of $F_{1}(k)$ with $k$.

The rooting scope of equation (14) is $(0,+\infty)$, and the first four-order frequency of the continuous beam can be obtained (as seen in Table 2). The change law of $F_{2}(k)$ with $\mathrm{k}$ is shown in Figure 5. With the increase of $k$, the vibration range of $F_{2}(k)$ has a magnitude of increase; on the curve, the wave peak and valley appear alternately. The $F_{2}(k)$ values of adjacent wave peak or wave valley have a magnitude of change.

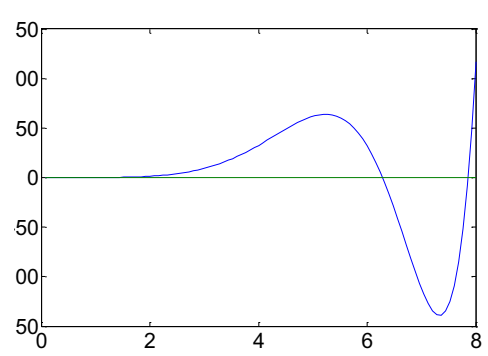

(a) Change law of $F_{2}(k)$ around $\omega_{1}$ and $\omega_{2}$.

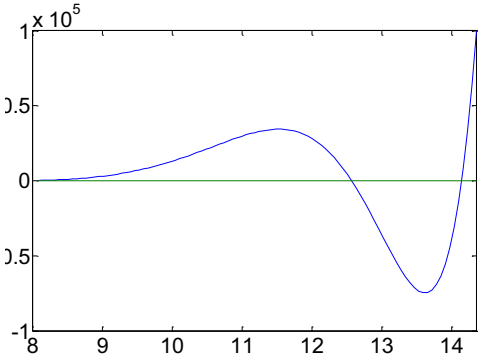

(b) Change law of $F_{2}(k)$ around $\omega_{3}$ and $\omega_{4}$.

Fig. 5. Change law of $F_{2}(k)$ with $k$.

Table 2. The first four-order frequency of two-span continuous beams with equivalent span lengths.

\begin{tabular}{|c|c|c|c|c|c|}
\hline Frequency & $\begin{array}{c}\text { Calculated according } \\
\text { to Jiao (2011) }\end{array}$ & $\begin{array}{c}\text { Calculated according } \\
\text { to equation (13) }\end{array}$ & $\begin{array}{c}\text { Calculated according } \\
\text { to equation (14) }\end{array}$ & $\begin{array}{c}\text { ANSYS } \\
\text { value }\end{array}$ & $\begin{array}{c}\text { Relative } \\
\text { difference (\%) }\end{array}$ \\
\hline$\omega_{1}$ & $(2 \pi)^{2}$ & $7.8532^{2}$ & $(2 \pi)^{2}$ & 39.4738 & 0.01 \\
\hline$\omega_{2}$ & $7.8532^{2}$ & $14.1372^{2}$ & $7.8532^{2}$ & 61.6671 & 0.01 \\
\hline$\omega_{3}$ & $(4 \pi)^{2}$ & $20.4204^{2}$ & $(4 \pi)^{2}$ & 157.8541 & 0.04 \\
\hline$\omega_{4}$ & $14.1372^{2}$ & $26.7037^{2}$ & $14.1372^{2}$ & 199.7786 & 0.04 \\
\hline
\end{tabular}

Note: The relative difference in the table is the difference between the theoretical value calculated by Jiao (2011) or equation (14) and the calculated value by ANSYS. 
According to Table 2, the frequency results calculated by Reference [5] and equation (14) are comprehensive with high calculation accuracy, and the difference compared with the calculation of ANSYS can be ignored. However, the results calculated by equation (13) missed the calculation of the asymmetric vibration mode. Hence, regarding the vibration of the two-span continuous beams with equivalent span lengths, the method introduced by Reference [5] is applicable but a little complicated; however, the two frequency equations (equation (13) and equation (14)) deduced by Reference [2] are not equivalent. Equation (13) can obtain only symmetric vibration mode results, while equation (14) can obtain all results needed.

Regarding the frequency equation of multi-span continuous beams with equivalent span lengths, consider the assumption that the determinant of equation (11) is 0 for the calculation, and convert it to the form of equation (14). Based on this method, the frequency equation of the three-span continuous beam with equivalent span lengths can be deduced:

$$
\begin{aligned}
F_{3}(k)= & \left(\sin \frac{k}{3} \cdot \sinh \frac{2 k}{3}-\sin \frac{2 k}{3} \cdot \sinh \frac{k}{3}\right)^{2} \\
& -\left(\sinh k \cdot \sin ^{2} \frac{k}{3}-\sin k \cdot \sinh ^{2} \frac{k}{3}\right) \times\left(\sinh \frac{k}{3}-\sin \frac{k}{3}\right)=0 .
\end{aligned}
$$

Table 3. The first four-order frequency of three-span continuous beam with equivalent span lengths.

\begin{tabular}{|c|c|c|c|}
\hline \multirow{2}{*}{ Frequency } & Theoretical value & ANSYS value & Relative difference (\%) \\
\hline$\omega_{1}$ & $(3 \pi)^{2}$ & 88.8162 & 0.01 \\
\hline$\omega_{2}$ & $10.6692^{2}$ & 113.8223 & 0.01 \\
\hline$\omega_{3}$ & $12.89258^{2}$ & 166.2021 & 0.01 \\
\hline$\omega_{4}$ & $(6 \pi)^{2}$ & 355.1718 & 0.04 \\
\hline
\end{tabular}

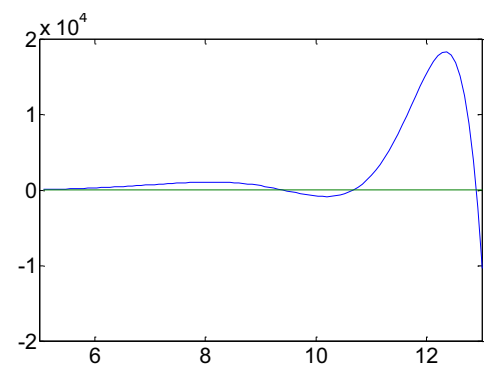

(a) Change law of $F_{2}(k)$ around $\omega_{1}, \omega_{2}$ and $\omega_{3}$.

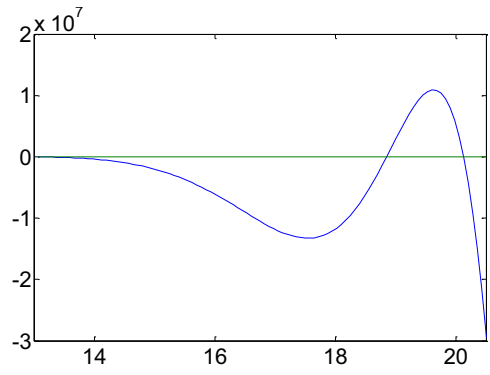

(b) Change law of $F_{2}(k)$ around $\omega_{3}$ and $\omega_{4}$.

Fig. 6. Change law of $F_{3}(k)$ with $k$. 
As shown in Table 3, the first four-order frequency can be obtained through equation (15). The change law of $F_{3}(k)$ with $k$ can be seen in Figure 6. Compared with the results calculated by ANSYS, the relative difference of the frequency value is very small and can be ignored; the two-order symmetric vibration mode appeared between the adjacent asymmetric vibration modes; with the increase of $k$ the wave peak and valley still appear alternately on the $F_{3}(k)$ curve, and the vibration range shows a magnitude of change.

\subsubsection{CONTINUOUS BEAMS WITH INEQUIVALENT SPAN LENGTHS}

For the frequency equation of continuous beams with inequivalent span lengths, it is still considered that the determinant of equation (11) is to be 0 for the calculation basis, and then will be converted to the form of equation of (14). When looking at the two-span continuous beam with inequivalent span lengths per the example in Figure 7, the frequency equation can be deduced as

$$
F_{4}(k)=\sinh k \sin k\left(1-\xi_{1}\right) \sin k \xi_{1}-\sin k \sinh k\left(1-\xi_{1}\right) \sinh k \xi_{1}=0 .
$$

The dimensionless coordinate of the middle bearing is $\xi_{1}=l_{1} /\left(l_{1}+l_{2}\right)$. Assuming $\xi_{1}$ is 0.5 , equation (16) will be degenerated to the frequency equation (14) of the two-span continuous beam with equivalent span length. The frequency of two-span continuous beams with inequivalent span lengths is shown in Table 4. The relative difference against the results of ANAYS analysis can be ignored.

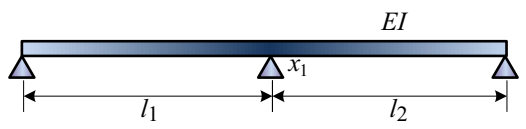

Fig. 7. Two-span continuous beam system.

For three-span continuous beams with inequivalent span lengths, the dimensionless coordinate of the middle bearing is $\xi_{1}=l_{1} /\left(l_{1}+l_{2}+l_{3}\right), \quad \xi_{2}=\left(l_{1}+l_{2}\right) /\left(l_{1}+l_{2}+l_{3}\right)$ (as shown in Figure 8$)$. Assuming that the coefficient determinant of equation (11) is 0 and is transformed into the form of equation (14), the frequency equation of the three-span continuous beam will be:

$$
\begin{aligned}
F_{5}(k) & =\left(\sin k \xi_{1} \sinh k \xi_{2}-\sin k \xi_{2} \sinh k \xi_{1}\right) \times\left[\sin k\left(1-\xi_{2}\right) \sinh k\left(1-\xi_{1}\right)\right. \\
& \left.-\sin k\left(1-\xi_{1}\right) \sinh k\left(1-\xi_{2}\right)\right]-\left[\sinh k \sin k\left(1-\xi_{2}\right) \sin k \xi_{1}\right. \\
& \left.-\sin k \sinh k\left(1-\xi_{2}\right) \sinh k \xi_{1}\right] \times\left[\sinh k\left(\xi_{2}-\xi_{1}\right)-\sin k\left(\xi_{2}-\xi_{1}\right)\right]=0 .
\end{aligned}
$$


Assuming that $\xi_{1}=1 / 3 、 \xi_{2}=2 / 3$, equation (17) will be degenerated to be the frequency equation of the three-span continuous beam with equivalent span length, which is known as equation (15). The frequency results of three-span continuous beams with inequivalent span lengths are shown in Table 5. The relative difference against the results calculated by ANAYS can be ignored.

Table 4. Frequencies of two-span continuous beams with inequivalent span lengths.

\begin{tabular}{|c|c|c|c|c|c|c|c|c|c|}
\hline \multirow{2}{*}{$\begin{array}{c}\text { Span length } \\
\text { ratio } l_{1} / l_{2}\end{array}$} & \multicolumn{4}{|c|}{$\omega_{1}$} & \multicolumn{3}{c|}{$\omega_{2}$} & \multicolumn{3}{c|}{$\omega_{3}$} \\
\cline { 2 - 10 } & value & ANSYS & $\begin{array}{c}\text { Relative } \\
\text { difference } \\
(\%)\end{array}$ & $\begin{array}{c}\text { Theoretical } \\
\text { value }\end{array}$ & $\begin{array}{c}\text { ANSY } \\
\mathrm{S}\end{array}$ & $\begin{array}{c}\text { Relative } \\
\text { difference } \\
(\%)\end{array}$ & $\begin{array}{c}\text { Theoretical } \\
\text { value }\end{array}$ & $\begin{array}{c}\text { ANSYS } \\
\text { difference } \\
(\%)\end{array}$ \\
\hline $1: 9$ & 17.868 & 17.863 & 0.028 & 58.237 & 58.236 & 0.002 & 122.114 & 122.109 & 0.004 \\
\hline $2: 8$ & 21.328 & 21.329 & -0.005 & 70.417 & 70.416 & 0.001 & 147.907 & 147.907 & 0 \\
\hline $3: 7$ & 26.335 & 26.334 & 0.004 & 86.061 & 86.059 & 0.002 & 138.778 & 138.771 & 0.005 \\
\hline $4: 6$ & 33.439 & 33.438 & 0.003 & 76.876 & 76.873 & 0.004 & 127.982 & 127.977 & 0.004 \\
\hline
\end{tabular}

Table 5. Frequencies of three-span continuous beams with inequivalent span lengths.

\begin{tabular}{|c|c|c|c|c|c|c|c|c|c|}
\hline \multirow{2}{*}{$\begin{array}{c}\text { Span length } \\
\text { ratio } l_{1} / l_{2} / l_{3}\end{array}$} & \begin{tabular}{c}
$|c|$ \\
\cline { 2 - 10 } \\
\cline { 2 - 10 } \\
Theoretical
\end{tabular} & ANSYS & $\begin{array}{c}\text { Relative } \\
\text { difference } \\
(\%)\end{array}$ & $\begin{array}{c}\text { Theoretic } \\
\text { al value }\end{array}$ & ANSYS & $\begin{array}{c}\text { Relative } \\
\text { difference } \\
(\%)\end{array}$ & $\begin{array}{c}\text { Theoretical } \\
\text { value }\end{array}$ & $\begin{array}{c}\text { ANSYS } \\
\text { Relative } \\
\text { difference } \\
(\%)\end{array}$ \\
\hline $4: 6: 2$ & 46.914 & 46.914 & 0 & 133.754 & 133.748 & 0.005 & 246.741 & 246.712 & 0.012 \\
\hline $2: 3: 5$ & 75.483 & 75.481 & 0.003 & 85.316 & 85.314 & 0.002 & 246.74 & 246.712 & 0.011 \\
\hline $2: 5: 3$ & 50.369 & 50.368 & 0.002 & 145.722 & 145.714 & 0.005 & 196.542 & 196.535 & 0.003 \\
\hline
\end{tabular}

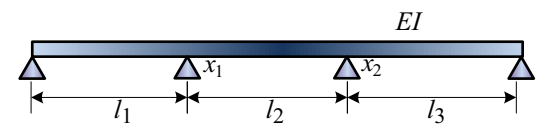

Fig. 8. Three-span continuous beam system.

Based on the above analysis, when using Laplace Transform to solve continuous beam vibration, it is possible to simplify the continuous beam into the single-span beam model, but the frequency equation form should be noted to avoid any misinterpretation of the solution. The frequency equation of the continuous beam is eventually transformed into the form of equation (14). The frequency solution is comprehensive with high accuracy, but the left side of the frequency equation vibrates greatly with the increase of the frequency calculation, which is a magnitude of change. 


\section{ANALYSIS OF THE APPLICATION METHOD BASED ON THE SEGMENTED BEAM MODEL}

Proceeding to the continual beam in segment, Laplace Transform was used to deduce the vibration equation of each segment of beam, to establish the simultaneous equation based on the continuity condition of each segment, to assume the equation coefficient determinant as 0 , and deduce the frequency equation of the continuous beam. The specified calculation method is shown as Reference [8]. Analysis showed that this process presents some problems. It used Laplace Transform and inverse transformation to obtain the algebraic equation (18) of a vibration differential equation of a beam segment. Then the deducing computation of the two sides of the equation (18) is conducted and equation (19) can be obtained:

$$
\begin{gathered}
Y(x)=C_{1} \sinh k x+C_{2} \sin k x+C_{3} \cosh k x+C_{4} \cos k x+\frac{M_{n-1}}{2 k^{2} E I}\left[\cosh \left(x-x_{n-1}\right)\right. \\
\left.\quad-\cos k\left(x-x_{n-1}\right)\right] u\left(x-x_{n-1}\right)+\frac{M_{n}}{2 k^{2} E I} \times\left[\cosh \left(x-x_{n}\right)-\cos k\left(x-x_{n}\right)\right] u\left(x-x_{n}\right), \\
Y^{\prime}(x)=C_{1} k \cosh k x+C_{2} k \cos k x+C_{3} k \sinh k x-C_{4} k \sin k x+\frac{M_{n}}{2 k E I}\left[\sinh \left(x-x_{n}\right)+\sin k\left(x-x_{n}\right)\right] \\
\times u\left(x-x_{n}\right)+\frac{M_{n-1}}{2 k E I}\left[\sinh \left(x-x_{n-1}\right)+\sin k\left(x-x_{n-1}\right)\right] u\left(x-x_{n-1}\right),
\end{gathered}
$$

where $u(\cdot)$ function is the step function or Heaviside function, which is usually expressed by $\mathrm{H}(\cdot)$. The value is:

$$
H(x)= \begin{cases}1, & x>0 \\ 0 . & x<0\end{cases}
$$

As a defined constant, $\mathrm{H}(x)$ has no derivative at $x=0$ [12], and its relationship with $\delta$ function is:

$$
\mathrm{H}(x)=\int_{-\infty}^{x} \delta(t) \mathrm{d} t= \begin{cases}1, & x>0 \\ 0, & x<0\end{cases}
$$

or

$$
\dot{\mathrm{H}}(x)=\delta(x) .
$$

Hence, the result of the two sides of equation (18) taking a derivative of $x$ should be: 


$$
\begin{aligned}
Y^{\prime}(x)= & C_{1} k \cosh k x+C_{2} k \cos k x+C_{3} k \sinh k x-C_{4} k \sin k x+\frac{M_{n-1}}{2 k E I}\left[\sinh \left(x-x_{n-1}\right)+\sin k\left(x-x_{n-1}\right)\right] \\
& \times u\left(x-x_{n-1}\right)+\frac{M_{n-1}}{2 k^{2} E I}\left[\cosh \left(x-x_{n-1}\right)-\cos k\left(x-x_{n-1}\right)\right] \delta\left(x-x_{n-1}\right)+\frac{M_{n}}{2 k E I} \times \\
& {\left[\sinh \left(x-x_{n}\right)+\sin k\left(x-x_{n}\right)\right] u\left(x-x_{n}\right)+\frac{M_{n}}{2 k^{2} E I}\left[\cosh \left(x-x_{n}\right)-\cos k\left(x-x_{n}\right)\right] \delta\left(x-x_{n}\right) . }
\end{aligned}
$$

According to the definition of $\delta(x)$ function, when $x \rightarrow 0, \delta(x) \rightarrow \infty$, which means $\delta(x)$ has no definition at $x=0$ [13]. Therefore, equation (23) is uncertain when $x=x_{n-1}$ and $x=x_{n}$, and the frequency equation deduction cannot be continued.

The frequency equation of the two-span continual beam can be deducted according to the vibration equation (equation (7) in the original paper) obtained by Reference [8].

$$
\frac{\cos k l_{1}}{\sin k l_{1}}-\frac{\cosh k l_{1}}{\sinh k l_{1}}+\frac{\cos k l_{2}}{\sin k l_{2}}-\frac{\cosh k l_{2}}{\sinh k l_{2}}=0 .
$$

Assuming that $l_{1}=l_{2}$, the frequency equation of the two-span continual beam with equivalent lengths will be:

$$
\frac{\cos k l_{1}}{\sin k l_{1}}-\frac{\cosh k l_{1}}{\sinh k l_{1}}=0
$$

Assuming that $l_{1}=l_{2}$, substituting into the frequency equation of the three-span continual beam in Reference [8] (equation (13) in the original paper), the frequency equation of the three-span continual beam with equivalent span lengths can be deducted as.

$$
2 \cot k l_{1}-2 \operatorname{coth} k l_{1}+\frac{1}{\sin k l_{1}}-\frac{1}{\sinh k l_{1}}=0
$$

Table 6. Frequencies of two-span continual beam with equivalent span lengths.

\begin{tabular}{|c|c|c|c|}
\hline Frequency & Application method (1) & Application method (2) & ANSYS \\
\hline$\omega_{1}$ & $(2 \pi)^{2}$ & $7.8532^{2}$ & 39.4738 \\
\hline$\omega_{2}$ & $7.8532^{2}$ & $14.1372^{2}$ & 61.6671 \\
\hline$\omega_{3}$ & $(4 \pi)^{2}$ & $20.4204^{2}$ & 157.8541 \\
\hline$\omega_{4}$ & $14.1372^{2}$ & $26.7037^{2}$ & 199.7786 \\
\hline
\end{tabular}

Note: Application method (1) is based on single-span beam model; Application method (2) is based on segmented beam model. Similarly hereinafter.

Table 7. Frequencies of three-span continual beam with equivalent span lengths.

\begin{tabular}{|c|c|c|c|}
\hline Frequency & Application method (1) & Application method (1) & ANSYS \\
\hline$\omega_{1}$ & $(3 \pi)^{2}$ & $10.6692^{2}$ & 88.8162 \\
\hline$\omega_{2}$ & $10.6692^{2}$ & $22.2886^{2}$ & 113.8223 \\
\hline$\omega_{3}$ & $12.89258^{2}$ & $29.5464^{2}$ & 166.2021 \\
\hline$\omega_{4}$ & $(6 \pi)^{2}$ & $41.1395^{2}$ & 355.1718 \\
\hline
\end{tabular}


It is clearly different from frequency equations (14) and (15) deduced according to the single-span beam model. The first four-order frequencies of the continual beams obtained from equation (25) and (26) are shown in Table 6 and Table 7. According to the analysis of the calculation, equation (25) and (26) can only provide results when the bearing is an asymmetric vibration mode. The reason is that the bending moment at the bearing is 0 , and actually the vibration differential equation of a singlespan beam in Reference [8] has no $\delta$ function.

Based on the above analysis, when using Laplace Transform to solve the vibration of continuous beams, the simplification of a continuous beam into a segmented beam model is improper. The reason is that the bending moment produced at the beam segment is situated at the two ends of a beam segment. This means $\delta(0)$ will appear in the equation based on the boundary conditions of the two sides of the beam, while $\delta$ function has no definition at $x=0$. In the static deformation of the continual beam, no $\delta(0)$ will appear. Hence, this method is proper in solving the static deformations of continual beams [14].

\section{CONCLUSION}

This paper presents a comparison of two types of simplified beam models for the free vibration of continual beams with Laplace Transform, and the main conclusions are as follows:

(1) When using Laplace Transform for the free vibration of a continuous beam, it is improper to simplify the continuous beam as a segmented beam model, which will give an incomplete solution; however, this simplified model is suitable for solutions of the static deformation of the beam.

(2) When the beam is simplified into the single-span beam model, Laplace Transform analysis is feasible. However, the resulting frequency equations will be of different and in-equivalent expressions. Hence, the frequency equation (14) is recommended for continuous beams, as it is effective for continuous beams with both equivalent and in-equivalent span lengths.

\section{ACKNOWLEDGMENTS}

This work is supported by the project of Science \& Technology Department of Sichuan Province, China (Grant Nos: 2015GZ0037); Process Equipment and Control Engineering Key laboratory Open Fund Project at Sichuan Higher Learning Schools, China (Grant Nos: GK201203); and Sichuan University of Science \& Engineering Fund Project, China (Grant Nos: 2015KY02). The authors are grateful to the anonymous reviewers whose work greatly improved this paper. 


\section{REFERENCES}

1. Y.A. Dugush, M. Eisenberger, "Vibrations of Non-Uniform Continuous Beams Under Moving Loads", Journal of Sound and Vibration, 254(5): 911-926, 2002.

2. J. Li, "A accurate method for the free vibration of multi-span continuous beam", Mechanics in Engineering, 2: 27-29, 1992.

3. C. H. He, L.Q. Liao, "The vibration of multi-span continuous beam”, Journal of Chongqing Institute of Technology Management, 9(4): 68-76, 1995.

4. S.Z. Yang, Y.J. Yang, G.J. Yang, "Eigenfrequencies characteristic analysis of the multi-span continuous beam with flexible supports", China science and technology achievements, 10(17): 27-31, 2009.

5. C.J. Jiao, J.M. Ding, "Analysis of natural frequency of prestressed composite beam with external tendons", Engineering mechanics, 28(2): 193-197, 2011.

6. K.H. Cai, et al, "A test in modal analysis of two-span continuous box girder bridge", Experimental Technol-ogy and Management, 30(2): 51-53, 2013.

7. Y.K. Zheng, X.R. Yuan, "Modal analysis test of a two-unequal-span continuous beam", Noise and Vibration Control, 34(4): 148-152, 2014.

8. H.M. Wang, S.H. Niu, S.Q. Gao, "Dynamic re-sponses of multi-span continuous beam due to human loads", Steel Construction, 30(194): 16-21, 2015.

9. L.N. Shi, et al, "Analytical solution for natural frequency of three-span bonded prestressed continuous beam", Journal of Chang'an University (Natural Science Edition), 35(4): 69-75, 2015.

10. Y.M. Jia, et al, "The frequency modification of vibration for the irregular continuous beam bridge", Journal of China \& Foreign Highway, 35(4): 150-153, 2015.

11. Y.D. Li, Y.R. Yang. "Forced vibration of pipe conveying fluid by the Green function method", Archive of Applied Mechanics, 84:1811-1823, 2014.

12. Q. Min, "The definition for $\delta$ function and its properties", College Physics, 23(9): 18-20, 2004.

13. L.L. Xu, Y.F. Zhao, X.G. Jing, "Dirac $\delta$ function", College Physics, 29(8): 16-17, 2010.

14. X.Z. Yuan, "Solving bending deflection of beam with Laplace's integral transformation", Mechanics in Engineering, 6: 37-41, 1983. 


\section{LIST OF FIGURES AND TABLES:}

Fig. 1. Multi-span continuous beam system.

Rys. 1. Wieloprzęsłowy system ciągłej wiązki.

Fig. 2. Equivalent system of multi-span continuous beam.

Rys. 2. Równoważny wieloprzęsłowy system ciągłej wiązki.

Fig. 3. The first fifth-order vibration mode of single-span beam.

Rys. 3. Pierwszy tryb drgań piątego rzędu w wieloprzęsłowym systemie ciągłej wiązki.

Fig. 4. Change law of $F_{1}(k)$ with $k$.

Rys. 4. Zmiana prawa z F1 (k) na $k$.

Fig. 5. Change law of $F_{2}(k)$ with $k$.

Rys. 5. Zmiana prawa z $F 2(k)$ na $k$.

Fig. 6. Change law of $F_{3}(k)$ with $k$.

Rys. 6. Zmiana prawa z $F 3(k)$ na $k$.

Fig. 7. Two-span continuous beam system.

Rys. 7. Dwuprzęsłowy system ciągłej wiązki.

Fig. 8. Three-span continuous beam system.

Rys. 8. Trójprzęsłowy system ciągłej wiązki.

Tab. 1. Main parameters of continuous beam.

Tab. 1. Podstawowe parametry ciągłych wiązek.

Tab. 2. The first four-order frequency of two-span continuous beams with equivalent span lengths.

Tab. 2. Pierwsza częstotliwość czwartego rzędu w dwuprzęsłowym systemie ciągłej wiązki o równoważnych długościach przęsła.

Tab. 3. The first four-order frequency of three-span continuous beam with equivalent span lengths.

Tab. 3. Pierwsza częstotliwość czwartego rzędu w trójprzęsłowym systemie ciągłej wiązki o równoważnych długościach przęsła.

Tab. 4. Frequencies of two-span continuous beams with inequivalent span lengths.

Tab. 4. Częstotliwości dwuprzęsłowych ciągłych wiązek o nierównoznacznych długościach przęsła.

Tab. 5. Frequencies of three-span continuous beams with inequivalent span lengths.

Tab. 5. Częstotliwości trójprzęsłowych ciągłych wiązek o nierównoznacznych długościach przęsła.

Tab. 6. Frequencies of two-span continual beam with equivalent span lengths.

Tab. 6. Częstotliwości dwuprzęsłowej ciągłej wiązki o równoznacznych długościach przęsła.

Tab. 7. Frequencies of three-span continual beam with equivalent span lengths.

Tab. 7. Częstotliwości trójprzęsłowej ciągłej wiązki o równoznacznych długościach przęsła. 


\section{ZASTOSOWANIE PRZEKSZTALCENIA LAPLACE'A W WOLNYCH DRGANIACH CIĄGLYCH WIAQZEK}

Slowa kluczowe: Przekształcenie Laplace'a, ciągła wiązka, drganie, dzielona metoda łączenia, częstotliwość

\section{STRESZCZENIE:}

Struktury ciągłej wiązki są bardzo często spotykane w projektach budowlanych. Przykłady obejmują: mostki ciągłej wiązki, stopy budynków, rury do wymiany ciepła w wymiennikach ciepła oraz wrzeciona obrabiarki. Nieodłączną częścią projektowania struktur ciągłych wiązek jest dynamiczna charakterystyczna analiza konstrukcji jako podstawy projektu antywibracyjnego. W celu uzyskania dynamicznych charakterystycznych parametrów struktur ciągłych wiązek, uczeni z kraju i z zagranicy przyjęli w celu poszukiwania rozwiązań liczne metody, w tym metodę elementów skończonych, metodę sztywności dynamicznej oraz metodę transferu matrycy. Metoda analityczna, w której wykorzystywane jest przekształcenie Laplace'a, mająca na celu rozwiązanie problemu wolnych drgań ciągłych wiązek, jest preferowana przez wielu badaczy i szeroko stosowana do rozwiązywania takich problemów w wielu dziedzinach. Niemniej jednak, istnieją pewne błędy w stosowaniu przekształcenia Laplace'a. W związku z tym, w niniejszej pracy przeprowadzono badania i analizę dotyczące różnych metod stosowania przekształcenia Laplace'a. Ponadto, w niniejszym dokumencie wyjaśniono metodę prawidłowego zastosowania przekształcenia Laplace’a podczas rozwiązywania problemu wolnego drgania ciągłej wiązki. Odpowiednie odniesienia przedstawiają dwie metody stosowania przekształcenia Laplace’a podczas rozwiązywania problemu drgania ciągłej wiązki. Pierwsza metoda opiera się na modelu jednoprzęsłowej wiązki. Ciągła wiązka jest traktowana jako jednoprzęsłowa ciągła wiązka, natomiast przeciwsiła elementów nośnych jest uznawana za nieznaną siłę zewnętrzną działającą na wiązkę, która posiada taką samą częstotliwość naturalnych drgań jak wiązki. Następnie, przekształcenie Laplace’a jest wykorzystywane do uzyskania równania częstotliwości oraz funkcji trybu drgań ciągłej wiązki. Druga metoda opiera się na modelu dzielonej wiązki. Ciągła wiązka jest dzielona pod warunkiem, że kąty na styku dwóch sąsiadujących przęseł są równe; przekształcenie Laplace’a służy do uzyskania równania częstotliwości i funkcji trybu drgań. Równanie częstotliwości ciągłej wiązki otrzymane na podstawie pierwszej metody nie jest unikalne. Wyniki rozwiązania wskazują, że te różne równania częstotliwości nie są równoznaczne, a niektóre wyrażenia mogą prowadzić do zaniechania rozwiązań; równanie częstotliwości, takie jak wzór (14) przedstawiony w niniejszej pracy, jest poprawne. Przyjmując dwuprzęsłową i trójprzęsłową ciągłą wiązkę jako przykłady, równanie prawidłowej częstotliwości różnego stosunku przęseł uzyskuje się na podstawie pierwszej metody zastosowania przekształcenia Laplace'a, natomiast wyniki częstotliwości zostały obliczone. W porównaniu z wynikami obliczeń oprogramowania skończonego elementu ANSYS, metoda ta charakteryzuje się wysoką dokładnością obliczeniową i wieloma zaletami w parametrycznym omówieniu pewnych czynników ciągłej wiązki. Rygorystyczne obliczenie dowodzi, że druga metoda jest błędna. po podzieleniu ciągłej wiązki, jej równanie częstotliwości uzyskane na podstawie przekształcenia Laplace'a może zawierać $\delta(0)$, lecz funkcja Dirac Delta nie jest określona na tym etapie, gdzie x jest równe 0. Traktując dwuprzęsłowe i trójprzęsłowe ciągłe wiązki jako przykłady, równanie częstotliwości uzyskiwane jest za pomocą drugiej metody, a wyniki częstotliwości są wówczas obliczane. Porównanie tych wyników z wynikami z pierwszej metody oraz z oprogramowaniem ANSYS skończonego elementu dowodzi, że druga metoda jest błędna. Natomiast druga metoda jest stosowana podczas rozwiązywania problemu statycznych odkształceń ciągłych wiązek, ze względu na brak $\delta(0)$ w procesie rozwiązywania problemu. 
Podsumowując, podczas rozwiązywania problemów drgań ciągłych wiązek nasuwają się następujące wnioski dotyczące stosowania przekształcenia Laplace'a:

(1)

Podczas stosowania przekształcenia Laplace’a dla swobodnego drgania ciągłej wiązki, niewłaściwe jest uproszczenie ciągłej wiązki jako modelu podzielonej wiązki, który stanowi niekompletne rozwiązanie; jednakże, ten uproszczony model sprawdza się w przypadku rozwiązań dotyczących statycznego odkształcenia wiązki.

(2)

Po uproszczeniu wiązki w modelu jednoprzęsłowej wiązki możliwe jest zastosowanie przekształcenia Laplace’a. Jednakże, równania częstotliwości będą stanowić różne i nierównoważne wyrażenia. Dlatego też, równanie częstotliwości (14) opisane w niniejszej pracy jest zalecane dla ciągłych wiązek. Jest ono skuteczne dla obu ciągłych wiązek, zarówno z równoważnymi i nierównoważnymi długościami przęseł. 